\title{
6 \\ The Types of Economic Resources Transmitted through the Networks of St. Petersburg IT Professionals
}

Practically everything where the price is not the only meaningful issue it is more effective to do through acquaintances.

(COO, director, p8)

This chapter describes what kinds of economically relevant resources are transmitted within the personal networks of St. Petersburg IT managers. The resources can be both material (transmitting goods, loaning money) and immaterial (passing on various kinds of information, giving advice) or rendering services (fixing a computer problem, helping to write a legal document).

The transmission of resources may be considered to comprise two successive phases or steps. In the first phase the problem is to find or locate the wanted resource, for example, an interesting job opening. In the next phase one has to secure the transmission of this resource, that is, get the job. Both steps can be conducted either through formal mechanisms or institutions or informally through social ties, or combining both approaches. In the first phase a job seeker could, for example, formally register at an employment agency or search for a job through personal connections. Once a suitable job opening is found, the candidate may rely on formal processing ( $\mathrm{CV}$, tests) or try to get someone to recommend him informally to the employer to get the job (Akhlaq 2005; for a classic account on job searches, see Granovetter ([1974] 1995).

This chapter focuses mostly on the first phase of locating the resources, while the second phase of securing the resources with the help of a third person is discussed in Chapter 7 in connection with brokerage. 
Unlike in many other fields of Russian industry, the beginning IT entrepreneur did not need a great amount of starting capital, employees, or a factory hall: the most important resources, that is, skill in problem-solving and the mathematical and programming abilities to go with it, were in his head. In the first phase of starting a company, these personal competences of the founder along with owning a personal computer and finding even one foreign customer could get the firm going: the projects implemented were small-scale or pilot projects and the founder's home could serve as a temporary office.

With the growth of the project or company, one also had to find a reliable business partner or partners and recruit more staff, for whom additional office space was needed. With increasing business activity, the self-taught entrepreneur had to obtain a wide variety of information and services concerning taxation, legislation, bookkeeping, financing, marketing, and so forth. Personal network ties were used both in locating and securing the transmission of these resources.

\section{Business ideas and partners}

In the 1980s and early 1990s, Western research on entrepreneurship shifted its emphasis from the heroic, individual entrepreneur to one embedded in social networks and started to address the role played by personal and business networks in the start-up phases of firms (Elfring and Hulsink 2003: 409).

Later research has confirmed the importance of network contacts during all stages of company formation starting from the initial idea of founding the firm (Hoang and Antoncic 2003). Researchers have investigated, for example, the optimal mix and functions of the 'strong' ties of family and friends on the one hand and 'weak' ties of acquaintances on the other (Uzzi 1996; Elfring and Hulsink 2003).

For the new Russian entrepreneurs, personal ties played an even more important role than in Western countries, since several tasks, which in developed capitalism could be conducted through market institutions, required help from one's personal network in the early 1990s in Russia. The picture emerging from our interviews concerning the start-up phase of the Russian IT field is in many ways similar to that reported by Ledeneva based on data from 1991-2 (1998: 184-5). ${ }^{1}$

As the launching of private businesses had not been attempted before, advice and help - for example, in presenting registration documents was essential. Most 'pioneers' of Russian business acknowledged 
that their registration documents were prepared by friends or contacts. Even when a paid service for drawing up documents became available, informal channels were reported to be an essential factor in starting a business. The advice or information obtained through friends and acquaintances was the advice and information considered reliable. Business was bound to depend on informal contacts, for 'the contract system was not yet developed. There were no efficient mechanisms for managing conflict situations or inflicting sanctions on unreliable partners'.

(Ledeneva 1998: 184-5)

Ledeneva concludes that the informal relations of trust formed in blat networks were 'the only guarantee one could rely on'.

While blat was an important factor for many of our respondents at some point of their careers (see Chapter 4), mutual help not related to blat was also crucial, as will become evident below.

Besides Ledeneva's, other studies lend credence to the importance of personal contacts for Russian start-up firms (e.g. Radaev 2003; Rogers 2006; Batjargal 2006). The 1993 survey of 277 Moscow entrepreneurs conducted by Vadim Radaev's group showed, for example, that 42 percent of them started their companies with personal acquaintances, 23 percent with friends and their kin, 17 percent with the entrepreneurs' own kin, and only 11 percent with unknown people (Radaev 2003).

Our data lend further credence to these findings. Many IT firms in St. Petersburg were born during the transition period when several institutions vital for a market economy, such as financial institutions, independent courts, effective law enforcement and so forth, were - and in many ways still are - either absent, functioning badly, or just about to emerge, and the whole society was penetrated by distrust. Thus, several of our respondents had turned to the help of their study mates, friends, relatives, or acquaintances to start their companies.

Dmitry's career (general director, p4), for example, began thanks to the suggestion of an emigrated friend of his parents who was running a firm abroad. The suggestion led Dmitry to establish a branch office of this firm with the spouse of his good acquaintance in St. Petersburg. The first employees were recruited from among his partner's circle of acquaintances.

In like manner, Nikita (technical director, p20) started a firm in 2004 together with his two friends and study mates from the university. ${ }^{2}$ Nikita's friends and acquaintances helped with registration of the firm 
and obtaining the working space, as well as solving problems with tax officials. In the beginning all orders were received 'either from acquaintances or friends', who still continue to assist in finding orders in addition to the orders found through other, more formal channels. Acquaintances were called for help also in cases of technical problems that could not be solved by the staff. Bookkeeping - often considered the most central function of a Russian firm - had also been entrusted to acquaintances, to whom the company also turned when encountering juridical problems.

Nikita's case was not an anomaly. Kirill (technical director, p38) and Stanislav (general director, p48) had started their firms with their wives, and Oleg's (project director, p26) wife worked for the same company as her husband. Andrey (general director, p1) established his firm together with his family members and Anton (p13) worked as a general director of the company founded by his study mate from the university. The central role of strong ties was similarly evident for Petr (PR-manager, p19), who had established a software company in the early 1990 s on the basis of a circle of friends and acquaintances. In the beginning the staff was mainly recruited through connections who also helped to solve technical, juridical, and financial problems.

This kind of developmental path led early on to the mixing of personal and professional spheres of life in the personal networks of St. Petersburg IT professionals - a theme to which we will return in the next chapter.

\section{Clients}

Finding clients and orders is the first and most crucial task for a fledgling IT company, and for our respondents personal ties were one of the main channels to find them. In the 1990s foreign customers were particularly valuable, since only one foreign client would provide enough income to pay a couple of Russian programmers, rent office space and start working on the first project:

Again we run into social networks. A father of one of the founders of the company used to work in Germany [name of the country has been changed]. The son had an opportunity to work there, and he made the acquaintance of the first customer of the firm, a German, who ran his own company. The German found out that the son was a programmer, and asked if he could write him a specific type of program. (...) After having heard the price of programming in Russia he wanted 
more. And the son was writing programs though the firm had not yet been founded. This was roughly the way the company was started.

(PR-manager, p2)

If the nascent company managed to assure the client of the quality of its work, another project followed, based on the relatively cheap and competent labor of the Russian programmers. After having established a successful business relationship, the company could get permission from the client to publish a reference on the company's website, thereby attracting other customers.

With the growth and professionalization of the company, personal relations continue to be important in finding clients, but are complemented by all possible means such as participating in software fairs, exhibitions and seminars, opening offices in other Russian cities or abroad, searching for customers through the Internet, and contacting potential customers directly:

My partner has over ten years' experience in the IT field, including quite big companies. On the one hand he has a collection of personal relations through which he can try to find potential clients (...) On the other hand he already has a certain reputation. In addition our company has customers who are very happy with our work and at times recommend us to others on their own initiative and thereby increase the clientele.

(director, p10)

\section{Starting capital}

After the first steps a growing business required more programmers, office space, computers, and other expenditures. Particularly for those interviewees who had started their commercial activity in the 1990s, finding starting capital to cover these costs was complicated because of the underdevelopment of the banking sector and the lack of alternative sources of financing. ${ }^{3}$ One of the interviewees who a started one-man small-scale programming business recalls:

At that time [early 1990s] the banking system functioned very badly. I do not mean the unreliability. Even under these uncertain circumstances people put money in the bank. I mean that everyone was pissed off that banks simply did not know how to work with money (...) in those years there were cases when money was paid [to an IT firm] 
but it was impossible to know by whom. One had to ask the client, 'have you by any chance sent me this sum?' Some also charged from one client 200 roubles and 50 copecks and from another one 200 roubles and 52 copecks in order to distinguish between the clients.

(programmer, p40).

Distrust of the banking system, the high level of interest rates, and the constant changes in the business environment made beginning entrepreneurs turn to their kin, family, and friends to obtain starting capital. In the early 1990s this was one of the few legal ways to get financing, but the following description from early 2007 shows how turning to banks was till recently an expensive choice for a St. Petersburg entrepreneur:

[A new IT company] can only get very small loans from banks. They are rarely tailored to the needs of companies, but rather for travel, leisure, health services or buying cars or apartments. The loans have extremely high interest rates, 18 percent is not unusual (...) It is difficult to start a business with a slightly over 10000 dollar loan with a high interest rate. For bigger loans one has to have collateral such as a new car or better a luxury apartment. Not many people have them. A big part of the new IT companies nowadays is searching for money from kin or friends or knocking at the doors of existing firms.

(general director, $\mathrm{p} 1$ )

The importance of social networks from the viewpoint of banks at the end of the 1990s has been described in the studies by Dinello (1999) and Guseva and Rona-Tas (2001, see also Uzzi 1999). Natalia Dinello interviewed Russian bankers during the banking boom of 1994 and at the onset of the crises in the summer of 1998. Her conclusion is that 'the F-connection' - that is, the relationships among financial outlets, firms, friends, families, and favorites - 'is pervasive and continuous and will likely outlast the market economy' (Dinello 1999: 24). Her interviewees rejected the possibility that Russian banking could be identityblind, only based on impersonal economic calculations, and supported the idea that it rather served primarily the inner circle of friends.

Though Guseva's and Rona-Tas's (2001) comparative study of Russian and American credit card markets - based on fieldwork conducted in summer 1998 and fall 1999 in Moscow - did not draw quite as drastic conclusions, the authors also stress the central role of social networks in banking. According to them, due to the inability of Russian banks to 
calculate risks, they relied on trust created by the social networks both of their own employees and their clients in issuing credit cards:

Reliance on existing networks of trust allows Russian banks to issue cards to families and friends of top bank executives (...) Here the borrower-creditor relationship is intermingled with close social bonds that serve as an additional guarantee and a channel of information. For instance, one interviewee was granted an American Express card by his friend, a high-ranking employee of AmEx in Moscow. Relying exclusively on personal relations necessarily limits the number of potential cardholders, however. The credit card market turns into an elite membership club, hardly a desirable market for a product whose profitability (and calculability) resides in its numbers.

(Guseva and Rona-Tas 2001: 638)

When assessing the studies of Dinello and Guseva and Rona-Tas, one must take into account the exceptional context of the 1990s and particularly the crisis of 1998. Presently, the Russian banking sector is extremely fragmented, consisting of a few large, Moscow-based and state-controlled banks, which form the backbone of the sector, and a great number of small banks. ${ }^{4}$ Though the total number of banks has decreased from 2084 in 2000 to 1243 in 2007, 'the great majority of the banks are still tiny and can hardly be called banks' (Fungáčová and Solanko 2008: 7-11).

The recovery of the banking sector after the 1998 crisis is due to many factors, among them the annual economic growth of more than 6 percent during the 2000s and institutional reforms. These reforms include the laws on private credit bureau operations, mortgage lending, and the deposit insurance system, covering in full private deposits of up to RUB 400,000 in March 2007 (Fungáčová and Solanko 2008: 7-11).

Despite the reforms, the distrust penetrating Russian society extends to banking. According to an interview in early 2007 with a Finnish banker with more than 20 years of experience in Russia, 'the Russians still prefer to draw their salary all at once from the ATM and put it in a safer place.' Though the ruble is the official currency, the amount of US dollars in cash in Russia is second only to that in the US (Kupila 2007). This distrust and the importance of connections in getting a loan were clearly expressed by one of our respondents:

The credit is given to industrial enterprises. But we are in the IT business. To get a loan, you need such an amount on paper ... fuck them. 
It is better to use your own money (...) It takes from two weeks to three months to get a loan, but you would need money tomorrow (...) The loans are given to acquaintances, on the basis of personal relations. This is how things are here.

(CEO, p12)

At the time of writing, the worldwide financial crisis had just hit Russia, and it was too early to assess its ultimate effects on either the world economy or Russia. Exceptional periods are, however, likely to increase the importance of personal contacts.

\section{Office space}

In addition to clients, business partners, and starting capital, office space was another central resource necessary for business activities that was located and secured through networks in the early 1990s. Growing turnover necessitated recruitment of additional employees who in turn needed working space furnished with a reliable telecommunications infrastructure:

We are sitting in this office because I know a person who knows the bankruptcy trustee of this factory. He phoned me and said, 'do you need office space?' I said 'of course.' When all others paid 12 dollars, I paid four. When all others pay 25, I pay 12.

(general director, p3)

Another respondent (COO, p8) similarly noted the role of his personal network ties in finding a new office for the company:

P8: One of our directors found out that her husband works in a holding company which was planning to open here a business center with another company. So we moved in here and this happened through acquaintances (po znakomstvu).

After the fall of the Soviet Union many Soviet organizations continued a 'shadow life' in their offices and buildings even though their Soviet functions had ceased to exist. It was possible to turn existing ties with the leaders of these organizations into important resources for a startup IT firm:

[During the Soviet era] my acquaintance knew the leader of the organization who administered this building. The leader was a 
high-ranking state official who had several offices in the city and he worked in the regional committee of the Communist party. He was the kind of old man (diaden'ka) with whom it was in general impossible to get an appointment. (...) My acquaintance phoned him, based on this old connection, and said that my good acquaintances will come to see you, probably you could rent this office to them (...) At that time, as you remember, there was no business and nobody had money. And many state departments and institutes simply rented out offices.

(general director, $\mathrm{p} 1$ )

Ledeneva (1998: 189) describes abuses and prosecutions that emerged in the Committee for the Management of City Property in St. Petersburg (Komitet po Upravleniiu Gorodskim Imushchestvom) after the appointment of a new director in 1991. With the economic growth in the 2000s several business centers have been established in the city and office space is now freely available on the market. For a small start-up firm, however, social relations still come in handy in acquiring office space.

\section{Jobs}

The significance of networks in obtaining a job is one of the basic findings of social network research since the classic study Getting a Job by Mark Granovetter ([1974] 1995). The main point of Granovetter's study was not only the observation that jobs were found through personal relations instead of through anonymous labor markets. Rather, his interesting and much disputed argument claimed that particularly the 'weak ties' of acquaintances (vis-à-vis the 'strong ties' of family and friends) were especially valuable in finding jobs.

Granovetter claims that a weak tie, such as a former classmate encountered by chance on the street, is more likely to provide new information from outside the job seeker's habitual social milieu. Even though strong ties are more motivated to help the job seeker to get the job, the information they have is more likely to already be familiar to the job seeker and thus redundant.

Our respondents' descriptions of the development of their own careers confirmed the significance of personal networks, including both strong and weak ties, in locating and securing a job in the Soviet Union and Russia (cf. Yakubovich 2005; Clarke and Kabalina 2000). But more importantly, personal networks were still an important channel 
for recruiting employees in St. Petersburg IT companies, a topic which emerged in several interviews.

According to the respondents, finding qualified staff had become one of the main problems in the IT industry: economic growth along with a limited number of university graduates and the entrance of international IT companies into the local labor markets had led to a shortage of labor and fierce competition for personnel. ${ }^{5}$

Under the conditions of the labor shortage, staff was recruited by all possible means, including ads, internet forums, recruiting agencies, and personal networks. Compared to anonymous recruiting, through ads for example, recruiting someone through personal relations was both quicker and cheaper. Especially in the beginning stages of start-up firms, recruiting through family, friends, or acquaintances could also guarantee the reliability of the employee.

On the other hand, several respondents brought up the disadvantage of using personal networks as a recruitment method: in the case of problems, friends and acquaintances are more difficult to fire. Similarly, with the growth and professionalization of the firm, the stakes, time, and costs related to recruiting grew, which made turning to a professional head-hunting firm a tempting option.

Many firms kept in touch with universities, whose graduates or advanced students were prime targets for recruiting. Since almost all respondents held a university degree, they already had previous ties to the university milieu.

Some firms had combined formal and informal methods of recruiting: one company paid a bonus to its staff members for bringing in a new employee; another asked job applicants to name their possible acquaintances among the company's employees, who were then inquired about the qualifications of the applicant (see next chapter).

\section{Advice and information}

Due to rapid technological development and a constantly changing business environment, networks could transmit information crucial to a company's competitiveness. A concrete example of this, in addition to getting orders or recruiting staff, was transmission of information concerning new technologies, markets, or legislation:

My brother, for example, has a close friend, who works in an organization that supplies companies with juridical information. We had to decide from whom to buy this information (...). He helped us to 
get an overall image and to understand, who, what and how, which organizations are offering what kind of services and how we could make a better choice. This, too, was done through acquaintances.

(general director, $\mathrm{p} 1$ )

According to another respondent (development manager, p17), information about employees' salary level was also exchanged with competing firms, which helped to 'keep an eye on things' and 'to understand if our salaries were lagging behind others'.

Information is an especially precious resource in the IT field, which is mainly based on information processing and where the share of material production is minor. In some cases social networks are the only way to obtain important information, since sensitive and valuable information about, say, tenders or actual projects is usually not made public:

In our business nobody shares information about concrete projects, because our business is about information. And the key to success is the protection of this information.

(technical director, p11)

The role of networks in the transmission of information is further underlined by the fact that many types of information that are easily available and formally distributed in most modern industrialized countries, such as credit registries, may be hard to obtain or totally lacking in Russia:

When you are closing a big contract, for example, it is important for you to know how capable your client is of paying. You want to talk with the firms or people who have been dealing with the client. This information is not public. If you have good relations with these people, they are willing to reveal this information as much as they wish, and this is very important. To get to know something about this client or theme.

(CEO, p16)

The specific feature of offshore companies compared to firms operating only in Russian markets was that the former rarely had to compete for the same customers due to the size of the global markets. Consequently, monitoring the actions of competitors in this regard was often not considered to be of primary importance. Instead, the firms competed 
fiercely on the local labor markets for employees, and the arrival of foreign competitors was important information for Russian firms:

Q: Do you often exchange useful advice or recommendations through acquaintances

P11: Yes, of course. (...) Usually this is news about technologies or labor markets. For example, when Intel arrived and recruited all the programmers. One had to know about this beforehand, so that one would not start a new project at the same time as they start their staff recruiting campaign

Q: But how can you know this beforehand?

P11: Usually some information exists (...) e.g. an office being set up. How would you get to know that Sun is opening a new office? Naturally only through some acquaintance.

(technical director, $\mathrm{p} 11$ )

One respondent referred to the exchange of information as 'gossip', which took place among acquaintances over informal lunches or dinners. If gossip is defined as 'the provision of information by one person (ego) to another person (alter) about an absent third person (tertius)' (Wittek and Wielers 1998), our interviews contain several examples of interviewees gossiping to the interviewer about competitors, enemies, or well-known figures in the St. Petersburg IT industry. The relatively small field of St. Petersburg's IT sector offered fertile ground for gossiping about third persons:

There are different kinds of gossip. There is gossip that is related to the mobility of staff, the behavior of clients, the strategic plans of well-known Moscow firms in St. Petersburg markets, to the serious problems and failures of certain companies. Or if one has to start hunting for personnel. Well, some kind of new information about which they don't write in the news (...) but which it pays to know in order to understand the context of many official events.

(general director, $\mathrm{p} 3$ )

\section{Services}

Not only information is transmitted through networks, but also concrete services related to, for example, technical and legal problems. A universal 'benefit' for IT professionals is the requests for help 
concerning the computing problems occurring in one's personal network of family, kin, and acquaintances. This feature was well known and several concrete examples of it were given in the interviews:

Here is a fresh example: Next to our office is hairdresser [field of the activity has been changed], where they continuously have problems with their computer. They stop by and I say, 'guys, whoever has time, go lend a hand.' And I myself regularly visit various friends precisely to fix computer problems. And my friends help me to solve some problems related to business administration. Someone works in state structures and I regularly turn to him for help in various problems. Q: What kind of problems? What was the latest case?

P4: I was interested in the credit system in the Russian Federation. I phoned my friends who work in a bank, consulted them and understood that in Russia this is not favorable. (...) And then, when opening an office I turned to my friend who works in fire protection. Q: Why?

P4: In order for an office to start working, it has to fulfill certain requirements concerning, among other things, fire protection. And if the landlord has not solved these problems, they fall upon the renter. I phoned, found out what I have to do in order not to have problems with fire inspection in the future.

(general director, $\mathrm{p} 4$ )

Nothing in the quote above implies that the employees of the hair salon next to the IT company were charged money for the computer maintenance services. Similarly, it is plausible to assume that, in the case that one of the staff of the IT firm was in need of a haircut, this was done for free.

The computing problems of the personal networks of an IT firm's employees are thus dealt with in an informal manner:

[The service department] is constantly dealing with these things installing computers. All my acquaintances go there all the time in a spirit of neighborliness, and someone helps. My home computer was also fixed this way.

(marketing manager, p15)

The interviews contained several examples of these kinds of exchanges crisscrossing the personal and professional spheres of life. The father of the boss-friend of Valentina (marketing manager, p15), for example, 
was a lawyer who took care of checking the contracts of Valentina's company. In a similar manner, Anna (PR-manager, p2) asked the lawyer of her firm to help Anna's friend in a law case:

A good example concerning the lawyers. Just a while ago my personal friends needed an attorney in a civil case. We have a lawyer in our firm who deals with contracts. I went to him and asked if he has some acquaintances at the [law] institute or in lawyer circles who have specialized in civil law. (...) Contacts were transmitted. Of course, this happens constantly. It is a constant practice.

(PR-manager, p2)

In the recently established company of Nikita (technical director, p20) 'many acquaintances from various fields' had provided concrete help for the firm in terms of registration, finding an office, taxation, server installation, bookkeeping, juridical advice, and advertising. As a next step he was planning to use his acquaintances to establish a front-end office in the US to draw in American customers.

In sum, these examples illustrate the significance of personal networks in Russian managers' business activities. The non-market exchanges effectuated through their personal ties provided them with a wide variety of both tangible and intangible resources. The next chapter will analyze the social mechanisms governing these transactions. 